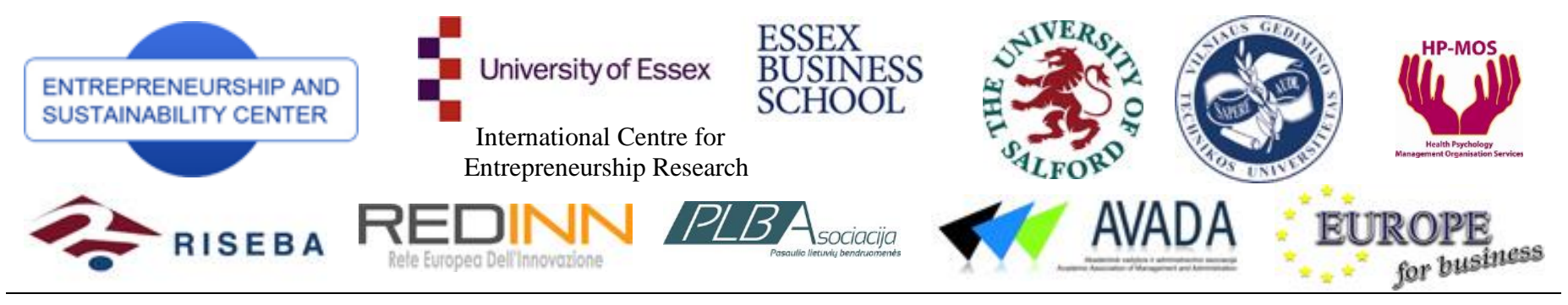

ENTREPRENEURSHIP AND SUSTAINABILITY ISSUES

ISSN 2345-0282 (online) http://jssidoi.org/jesi/aims-and-scope-of-research/

\title{
SUSTAINABLE YOUTH ENTREPRENEURSHIP IN CONDITIONS OF GLOBAL ECONOMY TOWARD ENERGY SECURITY
}

\author{
Ignas Dzemyda ${ }^{1}$, Jurgita Raudeliūniené⿱ \\ 1,2 Vilnius Gediminas Technical University, Sauletekio av. 11, LT- 10223, Vilnius, Lithuania \\ E-mails: ${ }^{1}$ ignas.dzemyda@vgtu.lt; ${ }^{2}$ jurgita.raudeliuniene@vgtu.lt
}

Received 2 June 2014; accepted 30 June 2014

\begin{abstract}
Sustainable entrepreneurship is seen today as a cultural and economic phenomenon. Sustainable entrepreneurship through the creation of new businesses that produce new products and services, and thereby ensure public needs, creates new jobs and contributes to the overall economic stimulus and community quality of life, balancing economic gain, regional development needs and environmental issues. Particular attention is given in recent years, to youth entrepreneurship, believing that young people have a lot of potential to create, develop and manage their own businesses, thereby contributing to a variety of social problems such as youth unemployment and unemployment in general, the involvement of anti-social activities, lack of employment to etc. Sustainable youth entrepreneurship is not analyzed much in scientific literature. In the article is defined sustainable youth entrepreneurship, discussed the importance of youth entrepreneurship for sustainability in the context of globalization, provided model of sustainable youth entrepreneurship toward energy security.
\end{abstract}

Keywords: sustainable entrepreneurship, youth entrepreneurship, global economy, energy security

Reference to this paper should be made as follows: Dzemyda, I.; Raudeliūnienė, J. 2014. Sustainable youth entrepreneurship in conditions of global economy toward energy security, Entrepreneurship and Sustainability Issues 1(4): 247-256.

http://dx.doi.org/10.9770/jesi.2014.1.4(7)

JEL Classifications: M10, Q01, Q43, F64

\section{Introduction}

Changing society raises new demands as human way of life requires the ability to adapt to environmental changes taking place and actively participating in terms of sustainability. It may be noted that life and communication goes beyond national borders - migration, globalization, international trade show that there are changes on human lives in a global society. In nowadays society it is very significant new powers, such as entrepreneurship. Entrepreneurial skills are important not only for the development of business, but also in finding work, planning career, making other important decisions in everyday life. Given the challenges of modern life, it is recognized that in order to flexibly respond to the changes, to ensure the development of society and quality of life, it is important to create conditions that will help young people to form and grow as active, responsible, creative personality, active citizens in society. Entrepreneurship involves various 
components, which allow young person actively engage in the processes taking place in society and contribute to its well-being.

Therefore, both Lithuania and the European Union has discussed ways of promoting youth entrepreneurship, in terms of what is necessary to ensure effective search for youth entrepreneurship models, development of strategies for both member states and the European Union. In order to rise a holistic approach to youth entrepreneurship, in the article entrepreneurship is seen as a system consisting of the inner personal provisions, skills and orientation, a constant desire to learn and improve skills and identify, take advantage of the favorable conditions and opportunities for business ideas. It is the ability to turn ideas into reality, and to create added value.

The concept of sustainability entrepreneurship is a new concept in management literature that is sometimes also named as sustainability entrepreneurship. The concept is developed by aim to relate sustainable development and entrepreneurship literature (Chesbrough 2007; Hall et al. 2010; Tvaronavičienè 2014). In this theoretical perspective sustainable entrepreneurship could be defined as a synthesis of conventional and social entrepreneurship. Sustainable entrepreneurship is a concept related to ability to find new opportunities, ability to realize and create economic, ecological and social value. The implication of the concepts in youth entrepreneurship is not analyzed much in scientific literature. Youth entrepreneurship is related with human personal motivation to find and use possibilities to create new added value, successfully develop business that could be understood as conventional entrepreneurship, more focused to meet minimum socio-ecological conditions defined by policy and law. As a contrary concept is social entrepreneurship, aiming to focus environmental and social problems, aiming to contribute to society, ensuring the economic viability of enterprise with social aims.

The article aims to define sustainable entrepreneurship and to make contribution to scientific literature, to define the model of sustainable youth entrepreneurship.

\section{Definition of sustainable youth entrepreneurship}

In order to describe the concept of sustainable entrepreneurship at the beginning is necessary to define the concept of entrepreneurship, which is dealt with in different scientific fields: economics, psychology, management, education science.

Entrepreneurship is seen today as a cultural and economic phenomenon. Entrepreneurship through the creation of new businesses that produce new products and services, and thereby ensure public needs creates new jobs and contributes to the overall economic stimulus and development of community life quality. Particular attention is given in recent years, to youth entrepreneurship, based on idea that young people have a lot of potential to create, develop and manage their own businesses, thereby contributing to a variety of social problems such as youth unemployment and unemployment in general, the involvement of anti-social activities, lack of employment and etc. From the economic position of the enterprise it is regarded as the organization to achieve results. In psychological sciences entrepreneurship is regarded as individual personal characteristics, traits, abilities in acting organization's success. From the science of management positions entrepreneurship is understood as an element of strategic management and seeks to identify the links between the organization's entrepreneurship skills and intentions.

Vinig and de Kluijver (2007) refer to the conditions of modern entrepreneurship to be considered in light of the growing importance and influence of the phenomenon of globalization. Therefore, the authors perceive entrepreneurship as a three-dimensional interface, including the ability to discover new opportunities; the ability to deploy and use existing resources to exploit discovered opportunities; participation in a global society and preparation for global competition.

Galloway (2009) argues that the concept of entrepreneurship can be fully understood just in case if will explore how the relationship between personal characteristics and personal knowledge and practical skills with a whole 
based on appropriate attitudes and learning. Galloway (2009) believes that organizational, communication, planning, problem-solving skills that can be learned are important for young people who want successfully develop their business; as well as perseverance, creativity, self-confidence, initiative, which is largely innate, although it can also be developed and strengthened; finally, teamwork and negotiation skills, foresight. The author points out that the analysis of young people's business, can be seen in the fact that it is individuals having a certain innate characteristics - these are the people who are able to attract others and inspire them to work together, to the inner self motivation are by nature curious and receptive to innovations. Župerka (2010) states that entrepreneurship is defined by characteristics of a person, values, skills, attitudes, provisions of own business building intentions. These few examples of the entrepreneurial concept definitions show that different authors emphasize different aspects of entrepreneurship. Some believe that the more important are the qualities that a person can acquire and develop (e.g., creative thinking, appropriate skills, etc.). Others more emphasize the internal personal orientations (e.g., determination, self-confidence, trust in intuition, etc.). Entrepreneurship is perceived and interpreted in three ways - inner dimension (the concept of entrepreneurship is treated as belonging to the individual and his ability to orientate the individual internal factors); the external dimension (the concept of entrepreneurship examines the emerging opportunities and conditions in the external environment on the market); integral approach (the concept of entrepreneurship is associated with the external and internal factors, as emerging opportunities outside of the individual's skills and changes in the circumstances, to take advantage of the changes) (Raudeliūnienè et al. 2014).

Since the famous Brundtland Report (World Commision on Environment and Development 1987), sustainable development is defined as a development 'that meets the needs of the present without compromising the ability of future generations to meet their own needs'. The relationship between entrepreneurship and sustainable development has been addressed by various streams of thought and literature such as: ecopreneurship environmentally orientated entrepreneurship; social entrepreneurship - entrepreneurship that aims to provide innovative solutions to unsolved social problems; institutional entrepreneurship, contributing to change regulatory, societal and market institutions, responsible entrepreneurship - a term coined which joining economic, technological, environmental factors is or must be responsible to society, enhancing the business positive contribution to society whilst minimizing negative impacts on people and the environment (Kardos 2012).

The concept of sustainable entrepreneurship can be defined by different theoretical ways. Therefore, sustainable entrepreneurship would be an area within the larger concept of sustainable development (Parra 2013). Sustainable entrepreneurship can be understood as the examination of how, by whom, and with what economic, psychological, social, and environmental consequences, the opportunities are discovered, created, and exploited to bring future goods and services into existence (Cohen, Winn 2007). From the process scope, it is the process of discovering, evaluating, and exploiting the economic opportunities present in market failures which detract from sustainability, including those that are environmentally relevant (Dean, McMullen 2007). As well sustainable entrepreneurship is defined as the teleological process aimed at the achievement of sustainable development by discovering, evaluating and exploiting opportunities and creating values that produce economic prosperity, social cohesion and environmental protection (Katsikis, Kyrgidou 2008). According to Lans et al. (2014), sustainability is a shared challenge with regard to economic (profit), social (people) and environmental (planet) goals for many parties in society. Sustainability is however not only something to act upon, complies with or engages in, but can also be seen as a major source for opportunities. The growing interest in sustainable entrepreneurship suggests that sustainability is an important addition to, or even a guiding element for, 'new' entrepreneurship, recognizing at the same time shortcomings of 'old' entrepreneurship. Opportunities with regard to sustainability are more complex than business opportunities, which address a one dimensional problem, remove a serious pain point, or meet a significant want or need. Sustainability opportunities have, in their rudimentary form, more the character of 'wicked' problems. Each sustainability opportunity should be approached as a new challenge. What worked in the past, does not necessarily work for the future (Lans et al. 2014).

According to Lans et al. (2014), the concept of sustainable entrepreneurship has gained importance over recent years. The relationship between entrepreneurship and sustainable development has been dealt with through 
various schools of thought, often resulting in the launching of new types of entrepreneurs, such as the ecopreneur and the social entrepreneur. The concept of 'sustainable entrepreneurship' has been coined more recently as an overarching way of looking at the contribution of entrepreneurial endeavors to social, ecological and economic aspects: or, in other words, sustainable development (Lans et al. 2014). According to Lans et al. (2014), in order to be able to recognize sustainable development as a business opportunity, sustainable entrepreneurs are in need of opportunity recognition skills, but also, for instance, interpersonal skills, which enables them to interact with, learn from and adapt to stakeholders.

From the analysis of the scientific literature can be noted that the concept of youth entrepreneurship involves many different aspects; so far there is no single definition of the concept. Youth entrepreneurship and entrepreneurial concept basically changed depending Chigunta (2002) who states that youth entrepreneurship can be understood as a process where young people learn about the business opportunity, or as a possible future; develop and implement their business ideas, learn to be entrepreneurs and initiate and develop their business ideas. It may be noted that the author emphasizes personal skills and competencies, which allow self-initiated and successfully manage their business. That is the meaning of entrepreneurship and many other scientists from those are concerned with this concept.

Strazdienè and Garalis (2008) also state that youth entrepreneurship - is a complex subject and personal skills that enable a young person to start a business and develop it. Such qualities and abilities authors attribute including creative thinking, initiative, receptivity, intuition, activity, willingness to act and etc. From the description can be noted that entrepreneurship involves not only certain abilities and skills a person can learn, but some inner personal preferences that enable to be proactive and take advantage of existing opportunities to implement ideas. That internal perception and willingness to act in a focused and coherent way in order to develop and implement business ideas is the basic concept of entrepreneurship.

Sustainable entrepreneurship is the process of identifying and starting a new business venture, organizing and managing needed resources, thinking both risks and revenues related with the venture, while considering of how, by whom, and with what economic, psychological, social, and environmental consequences, the opportunities are discovered, created, and exploited to bring future goods and services into existence. Sustainable youth entrepreneurship in the context of globalization is very much affected by increase of quality of, by various processes of globalization, and by changed needs and behavior of consumers.

\section{The importance of youth entrepreneurship for sustainability in the context of globalization toward energy security}

Modern society has formed new conditions of globalization, which has a significant impact on business - the rapid development of technology, hyper-competition, constant change, information flows, etc. provides both new opportunities and new challenges. Under these conditions is increasing scientific and political interest in youth entrepreneurship and the impact of the international economy, the business processes of sustainable development. Searching for the most effective ways of promoting youth entrepreneurship, recognizing that youth entrepreneurship globalization provides important features of society: innovation, active involvement and concern for its quality of life and progress, productivity, and ability to detect and exploit opportunities.

Shastri, Kumar and Ali (2009) state that youth entrepreneurship is important not only at the level of the individual, but also society, the global level, because what through its initiative, skills and ability to create innovative ideas for a young person to contribute not only to their own quality of life improvement but also to the general quality of life. The authors point out those societies youth entrepreneurship among young people and active participation in business is important in that it provides:

- financial benefits to the person; independence, the creation of jobs;

- development of new industries, especially in rural areas and less developed regions;

- promotion of the export of local resources and the recycling of valuable goods, products and services;

- healthy competition and the development of new markets;

- research, study and technology development; 
- entrepreneurial characteristics and the proper approach to self-promotion activities, which in turn promotes the development of the various regions and local communities increase the quality of life;

- the ability to achieve excellent results in their professional career, which increases life satisfaction, and hence improve the psychosocial health of the public;

- reduction of the shadow economy; emigration and talent loss.

The authors point out a number of important factors that contribute to the improvement of society and quality of life. Youth entrepreneurship is an important advantage in that it enables young people to constantly look for and promote change, and change-driven globalization not realize the risks, and how options can be used to promote the progress of society. As well as the benefits of youth entrepreneurship is that it is the creation of new jobs, and young people are able to foster and maintain relationships on a global scale, thus bringing in new ideas and investments in innovation and active participation in the global society, which encourages young people's interest in and concern about global problems and their decision. It can be argued that globalization promotes youth entrepreneurship properly helps to increase young people's awareness of global issues and their responsibility for what is happening in the world to work together to solve global problems and promote wellbeing.

Chigunta (2002) states that youth entrepreneurship has social and economic benefits, which primarily affects the right of young people in terms of business, increased activity of society in economic and social life and greater responsibility for promoting positive changes in society. Young people who had the right conditions and opportunities to realize their business ideas, has the following provisions of the business vision, business discipline, positive attitude with regard to the business sector, the ability to identify and exploit new business opportunities, patience to the results of the perseverance and endurance, the ability to quickly recover from the experience of failure. This ensures that young people grow responsible, active members of society who contribute significantly to the development of the business sector.

To summarize the above opinions of different authors, it can be seen that the promotion of youth entrepreneurship has a positive impact on both the individual level and the social level (Figure 1).

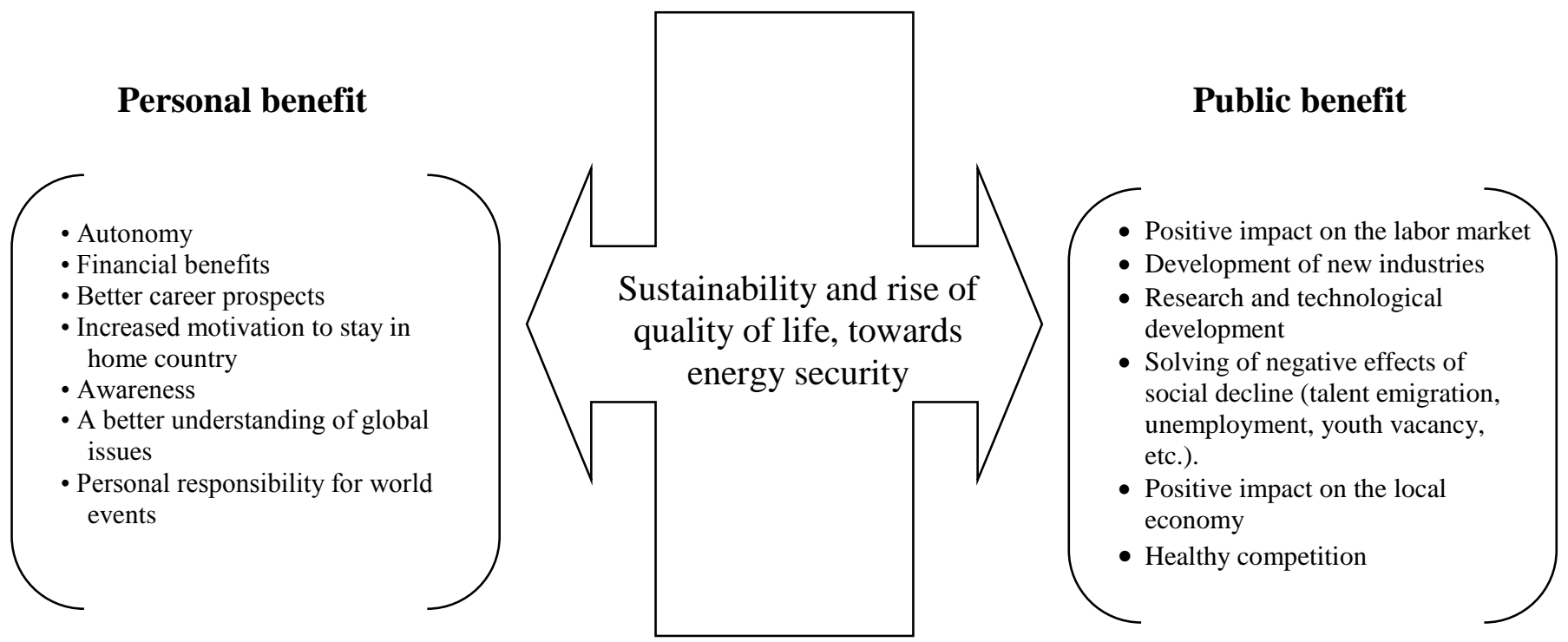

Fig.1. The importance of sustainable youth entrepreneurship in the context of globalization toward energy security

Source: created by authors

From the figure it can be seen that the promotion of youth entrepreneurship combines the personal and social benefits and thus is an improved quality of life in the new conditions stipulated by the process of globalization. 
Vinig and de Kluijver (2007) state that youth entrepreneurship is influenced by different aspects of globalization. The authors distinguish three main forms of globalization that affect entrepreneurship:

1. economic globalization - many companies and organizations, and business ideas coming out in several countries; is created and developed in international relations global business;

2. political globalization - is being developed by international standards and national policy, is influenced by global events. All of this has an impact on the business sector, youth entrepreneurship;

3. social globalization - which gets more opportunities, including young people, to exchange ideas and information with people all over the world, to communicate with people in different countries. This particularly facilitates information technology, various youth exchange programs and etc.

This indicates that youth entrepreneurship is influenced by the conditions of globalization processes. Although most authors state that such conditions create additional opportunities for young people in the activities, but it also means that youth entrepreneurship is gaining global importance, and globally the state has to create certain conditions that will enable young people to act independently of increased competition. In this aspect sustainable youth entrepreneurship is much related with energy security as sustainability values have positive impact for energy efficiency over wide geographical areas.

It is important to create the right conditions for sustainable youth entrepreneurship. Chigunta (2002) states that the most important factors that need to be fulfilled in order to promote youth entrepreneurship is access to working capital; access and use of the latest technology and equipment; new product development and allowing young people to try out its ideas in practice, creating added value. Thus, the greatest importance to the promotion of youth entrepreneurship is a practical help to young people, especially the necessary resources and programs that help young people to develop and strengthen their entrepreneurial skills. The author also points out that the global level is necessary to promote the importance for youth entrepreneurship as entrepreneurial skills development programs; business consultancy; mentors (managers) support; access to jobs (access to spaces for their work/ideas), support for young people in the business development of local, national and international support networks. These provisions are usually more or less based on the different countries as well as international youth entrepreneurship promotion programs and recommendations.

\section{Modelling sustainable youth entrepreneurship towards energy security}

The concept of business model is becoming more popular and extensively researched in managerial and strategic management literature. However, as the young entrepreneurial terms, and as a business model, there is no precise definition of the business model.

Business model components are defined in many different ways and different authors indicate quite different components. Hedman and Kalling (2003) state that the main components of the business model include: customers, competitors, proposals, activities and organization, resources, and costs of production. Meanwhile, the business model can be characterized by three main components - the outer environment, its needs and values; what you can offer the same organization and internal aspects, such as organizational structure, resources, knowledge and skills, systems and values.

As regards the youth entrepreneurship is indicated that youth entrepreneurship should be developed in addition to the business model of some aspects which shows that young people need assistance and support in developing and implementing its business ideas. Clemensson and Christensen (2010) points out that youth entrepreneurship model includes several key components. First of all, it is the development of an entrepreneurial culture according to the authors, social and cultural attitudes, along with the young person's values and orientations have a very significant impact on whether a young person will have the determination to start their own business. 


\section{External enviroment}

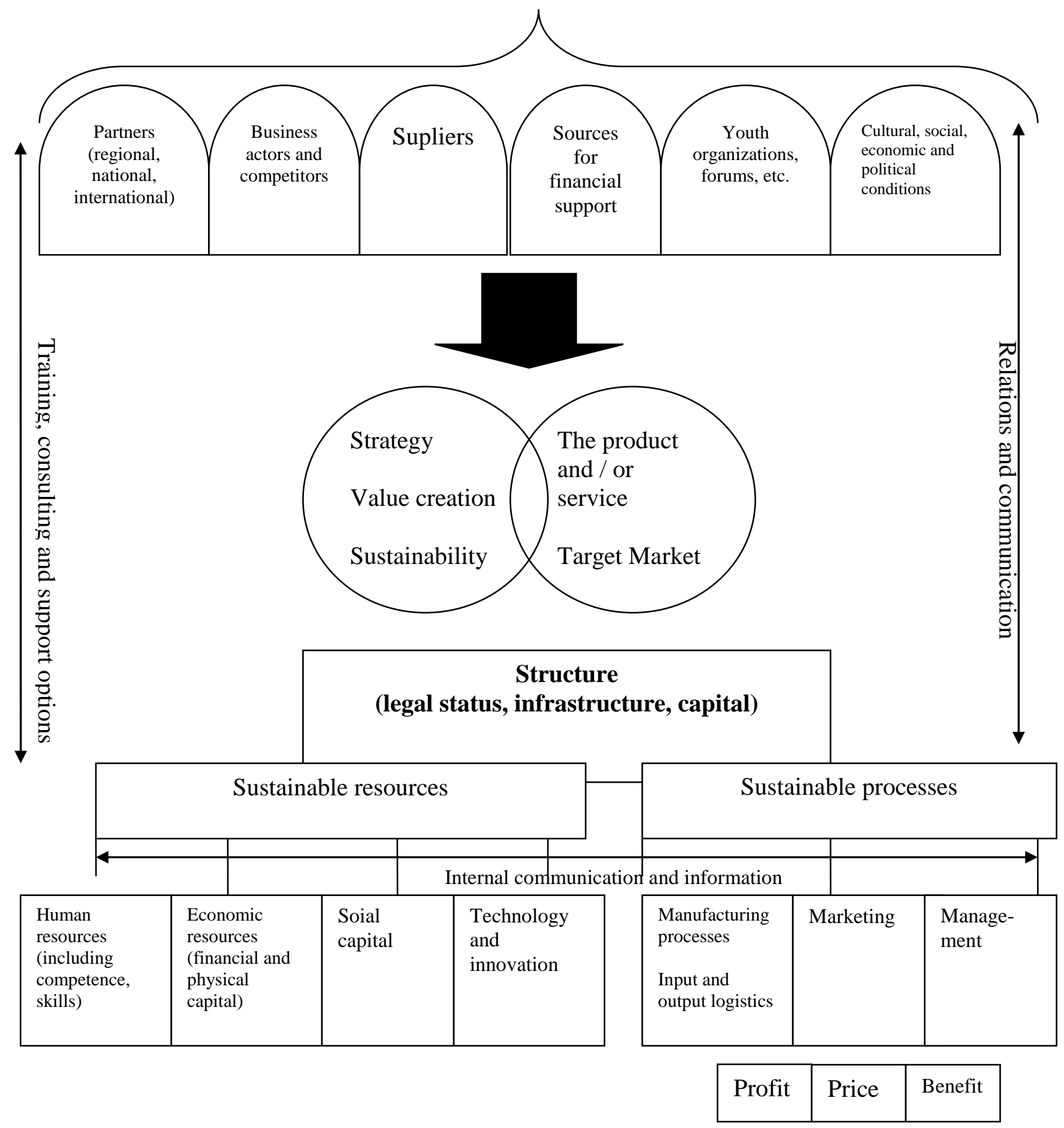

Fig.2. Sustainable youth enterpreneurship model

Source: created by authors

According Clemensson and Christensen (2010) as a separate component of youth entrepreneurship model, indicating that no youth entrepreneurship strategy or model will be successful if young people are not able to gain knowledge about the business and its development, and to develop and strengthen the skills needed for 
business development and management. However, the authors emphasize that entrepreneurship education must include not only the business knowledge and skills, but also the appropriate provisions relating to entrepreneurship and skills for the benefit of young people in other areas of life, their community and the general public. It also shows the importance of youth entrepreneurship not only to the individual, but also society in general.

Created laws and policies should promote opportunities for young people to start and develop their business. The important component of youth entrepreneurship model is business development services and support programs and schemes. In this case, is especially popular with business associations, the business jointly develop and provide the opportunity for young people to realize their ideas, try your hand, access to business principles. As well as other widespread assistance and support in the form of business mentors - this can be either businesses or youth workers who support young people, who advise them, help them to get the necessary information. The sustainable youth entrepreneurship model is provided in Figure 2.

It can be noted that sustainable youth business model includes traditional business model components. These are: structure, capital, resources, manufacturing and other processes, technology, information and communication, both internally and externally. However, the proposed model includes also specific components. First, the external environment acquires great importance of youth organizations, as well as funds, programs, and other sources that provide young people with a broad range of support (financial, consulting, training, etc.). Also, young people who start their own business, to develop their skills and knowledge to be able to self-manage their business ideas to implement it. Another important aspect is that promoting youth entrepreneurship, it is important to develop a culture of entrepreneurship, to form suitable for both young people and society in general provisions relating to the business, the business benefit to the community and society.

\section{Conclusions}

Sustainable entrepreneurship is a new concept and a very progressive one to achieve success of small and medium enterprises in a very complex competitive environment. Sustainable entrepreneurship could be defined as the process of identifying and starting a new business venture, organizing and managing needed resources, thinking both risks and revenues related with the venture, while considering of how, by whom, and with what economic, psychological, social, and environmental consequences, the opportunities are discovered, created, and exploited to bring future goods and services into existence. Sustainable youth entrepreneurship is a perceived and recognized as an important issue in today's young people's choice, most young people can build and develop their business, and thus increase quality of life, and contribute to a positive change in global society in terms of sustainability and energy security.

Youth entrepreneurship model has certain specific components, because young people need extra help and support to get started developing business idea, to implement and maintain them. Therefore, it can be noted that youth entrepreneurship model specific components mainly relate specifically to support young people - young people need to understand the business aspects of the knowledge and skills relevant to the implementation of business ideas and development. Understandings of principles of sustainability are very important in youth entrepreneurship to achieve sustainable competitive advantage in regional context. It is recognized that the proper focus on youth entrepreneurship helps to promote business in the country, to enable the dynamic economic development of rapid globalization, the creation of new jobs, which in turn help to reduce unemployment, social exclusion and to address other social issues, as well as to help to solve ecological issues.

Discussed the concept of sustainable youth entrepreneurship, youth entrepreneurship situation of globalization and the need to promote opportunities for young people to build their own business, as well as youth entrepreneurship models reveals the basic theoretical aspects of youth entrepreneurship. It may be noted that youth entrepreneurship is becoming increasingly important in today's society - it is believed that the opportunities for young people to realize their business ideas are important not only on a personal level, but contribute to overall public good, as well as sustainability toward energy security. Theoretical analysis shows that it is believed that the opportunities for young people to develop and implement their business ideas are 
important not only for them, but also in the community, society in the terms of sustainability, social cohesion, regional development and energy security. This also allows the creation of additional jobs, activating the young people and enables them to take the initiative to self-realization.

As the youth entrepreneurial success largely depends on the conditions created to promote youth entrepreneurship in different countries and in general, it is important to analyze the key policy objectives, youth entrepreneurship situation.

\section{References}

Chesbrough, H. 2007. Business model innovation: it's not just about technology anymore, Strategy \& Leadership 35(6): 12-17. DOI: $10.1108 / 10878570710833714$

Chigunta, F. 2002. Youth Entrepreneurship: Meeting the Key Challenges. London: Oxford University.

Clemensson, M.; Christensen, J. D. 2010. How to build an enabling environment for youth entrepreneurship and sustainable enterprises. Paper for the knowledge sharing event on Integrated Youth Employment Strategies, Moscow 17-19 February, 2010. International Labour Organization: Geneva.

Cohen, B.; Winn, M. 2007. Market imperfections, opportunity and sustainable entrepreneurship, Journal of Business Venturing 22: 2949.

Dean, T.; McMullen, J. 2007. Toward a theory of sustainable entrepreneurship: reducing environmental degradation through entrepreneurial action, Journal of Business Venturing 22: 50-76.

Galloway, L. 2009. Diversity in entrepreneurship: the role of women and ethnic minorities, in Deakins, D. and Freel, M. (Eds.). Enterpreneurship and Small Firms. London.

Hall, J.; Daneke, G.; Lenox, M. 2010. Sustainable development and entrepreneurship: past contributions and future directions, Journal of Business Venturing 25(5): 439-44.

Hedman, J.; Kalling, T. 2003. The business model concept: theoretical underpinnings and empirical illustrations, European Journal of Information Systems 12: 49-59.

Kardos, M. 2012. The Relationship between entrepreneurship, innovation and sustainable development, Research on European Union Countries, Procedia Economics and Finance 3: 1030-1035. DOI: 10.1016/s2212-5671(12)00269-9

Katsikis, I.; Kyrgidou, L. 2008. The Concept of sustainable entrepreneurship: a conceptual framework and empirical analysis, Academy of Management Proceedings: $1-6$.

Lans, T; Blok, V.; Wesselink, R. 2014. Learning apart and together: towards an integrated competence framework for sustainable entrepreneurship in higher education, Journal of Cleaner Production 62: 37-47.

Parra, S. 2013. Exploring the incorporation of values for sustainable entrepreneurship teaching/learning, Journal of Technology Management \& Innovation 8 (1): 11-20.

Raudeliūnienè, J.; Tvaronavičienè, M.; Dzemyda, I. 2014. Towards economic security and sustainability: key success factors of sustainable entrepreneurship in conditions of global economy, Journal of Security and Sustainability Issues 3(4): 71-80. DOI: http://dx.doi.org/10.9770/jssi.2014.3.4(7)

Shastri, K.; Kumar, S.; Ali, M. 2009. Entrepreneurship orientation among Indian professional students, Journal of Economics and International Finance 1(3): 85-87.

Strazdienè, G.; Garalis, A. 2008. Imitacinès verslo įmonès modelis: teoriniai ir praktiniai aspektai [The Model Of Simulation Business Enterprise: Theoretical And Practical Aspects], Organizaciju vadyba: sisteminiai tyrimai [Management of Organizations: Systematic Research] 46: 133-147.

Tvaronavičienè, M. 2014. If industrial sector development is sustainable: Lithuania compared to the EU, Entrepreneurship and Sustainability Issues 1(3): 134-142. DOI: http://dx.doi.org/10.9770/jesi.2014.1.3(2)

Vinig, T.; Kluijver, J. 2007. Does Globalization Impact Entrepreneurship? Comparative Study of Country Level Indicators. Netherlands: University of Amsterdam. 
World Commission on Environment and Development. 1987. Our Common Future. Oxford: Oxford University Press. p. 27. ISBN 019282080X.

Župerka, A. 2010. Studentų verslumo ugdymo plètra Lietuvoje [Development of students' entrepreneurship education in Lithuania]. Daktaro disertacijos rankraštis Vytauto Didžiojo universitetas [Doctoral thesis, Vytautas Magnus University], 185 p. Available on the Internet: http://vddb.laba.lt/fedora/get/LT-eLABa-0001:E.02 2010 D 20101230 091557-86520/DS.005.0.01.ETD

Ignas DZEMYDA. Assoc. Prof. Dr. of social sciences at the Faculty of Business Management, Vilnius Gediminas Technical University. The author carries out research in the fields of sustainable entrepreneurship, international management and the EU regional integration. He has published number of scientific research articles on various issues of management and economy. Research interests: strategic management, regional development, higher education, export development, innovations, new public management, sustainable entrepreneurship.

Jurgita RAUDELIŪNIENĖ. Assoc. Prof. Dr. of social sciences at the Faculty of Business Management, Vilnius Gediminas Technical University. The author and co-author of more than 20 scientific papers. Research interests: knowledge management, formation and evaluation of competitive strategic decisions.

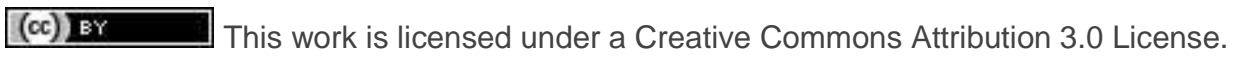

